\title{
Addressing new challenges in climate change research by highlighting biological complexity
}

\author{
Eric Post ${ }^{1}$ and Frank Seebacher ${ }^{2^{*}}$
}

In the study of ecological and evolutionary responses to climate change, there has been a growing emphasis recently on complexity deriving from biological interactions [1-3]. Such complexity reflects the dynamics of interactions occurring among levels of organization and across scales of space and time. It therefore poses enormous challenges for the management of global environments and resources over the next century. Climate Change Responses is dedicated to publishing research that addresses this complexity and confronts these challenges to understanding biological responses to climate change. With the launch of this journal, we aim to emphasize the frontiers in climate change research, including, for instance, understanding interactions among individuals and species, bi-directional interactions between abiotic and biotic components of natural systems, and evolutionary capacities to respond to changing environments through adaptation and phenotypic plasticity.

The probability that the observed changes in climate since the mid $20^{\text {th }}$ century are not caused by human activity is now diminishingly small [4]. Human activity has therefore led to changes in several environmental variables, notably temperature, dissolved oceanic $\mathrm{CO}_{2}$ level, and rainfall patterns. In addition to their individual impact, environmental drivers interact with each other, thereby exacerbating their effects on biological systems. For example, concurrent increases in temperature and $\mathrm{CO}_{2}$ levels can interact to determine metabolism and gene expression profiles in marine invertebrates [5]. Similarly, together temperature and UV-B radiation can determine performance and life history traits in animals [6]. Quantifying climate change at the spatial level at which it is most relevant for ecological responses is, however, far from straightforward [7]. This is because climate change predictions are mostly made at a global scale over relatively long time periods. However, Helmuth et al. [7]

\footnotetext{
* Correspondence: frank.seebacher@sydney.edu.au

${ }^{2}$ School of Biological Sciences, University of Sydney, Sydney, NSW 2006, Australia

Full list of author information is available at the end of the article
}

argue that these general patterns in climate do not necessarily encapsulate regional or local climate patterns and weather, which ultimately affect the physiology, behaviour, and interactions of organisms. Spatial and temporal resolutions need to be incorporated into experimental designs explicitly, and will have consequences for management strategies and communication about climate change responses among (human) stakeholders [7].

The consequences of changes in local weather conditions resulting from the interaction between environmental drivers are dramatically illustrated by the long-term effects of the 1997-1998 El Niño patterns in the Pacific. El Niño events, resulting from anomalously high sea surface temperatures, cause increased rainfall in certain regions of the eastern Pacific. Heavy rains can in turn disrupt food supplies and increase the risk of disease outbreaks in human populations. Malnutrition during early childhood may have effects, such as smaller size and lower metabolic rates [8], that persist into adult life. The particularly welldeveloped El Niño pattern of 1997-1998 caused massive flooding events in Peru. Danysh et al. [9] show that children born during this El Niño season showed significantly reduced height and lower lean mass 10 years after the event, compared to cohorts born before or after it. El Niño events are predicted to increase in frequency and severity with global warming, so that the ensuing weather patterns may have a lasting and increasing effect on the health of humans and possibly other species [9].

A second example of the long-term effects that local conditions can have on species phenotypes, and potentially species persistence, comes from sex determination in turtles [10]. As in other reptiles, sex in flatback sea turtles (Natator depressus) is determined by the incubation temperatures experienced during development by the eggs. Flatback turtles lay their eggs in nests dug into beaches in Australia, Indonesia and New Guinea, and offspring sex ratio in this species is determined by nest sand temperatures Stubbs et al. [10]. Show that the sand temperature that produces equal numbers of males and females is $29.4^{\circ} \mathrm{C}$; lower temperatures produce male- 
biased, and higher temperatures female-biased sex ratios. In the past 20 years, cooler sand temperatures led to a slight male bias in hatchling sex ratios. However, modelling the impact of climate change in the region shows that increasing temperatures resulting from climate change may bias the sex ratio towards females by the mid $21^{\text {st }}$ century. Interestingly, however, climate at the location of the focal population in northern Australia is predicted to become increasingly variable, which means that the higher extremes reduce hatching success in the offspring. Winter temperatures, however, may also decrease so that at this particular location the population may remain male-biased if nesting occurs in winter.

Over the past two or three decades, climate change has in many diverse systems caused pronounced changes in the timing of biological events such as flowering and growth in plants $[11,12]$ and the seasonal appearance of invertebrates [13]. At the same time, the geographical distributions of many animals, plants, and other organisms has changed as a result of regional climate changes [14]. Compensation for environmental changes at the level of the phenotype may confer resilience to climate change, the degree of which may differ between different species or populations. Phenotypic plasticity in response to environmental variability can result from developmental or reversible processes within individuals, or from genetic adaptation across several generations $[15,16]$. More generalist phenotypes and those with greater capacity for within-individual plasticity are likely to be more resilient to change. For example, in a community of bumblebee species of the genus Bombus distributed along an altitudinal gradient some species are cold adapted and their distribution is restricted to high altitudes. Other species have wider distributions across lowland areas [17]. Climate warming will affect the cold-adapted species more severely, and will cause contraction of their range to increasingly higher altitudes. At the same time, the lowland species will extend their range to higher altitudes. Cold tolerance is associated with proboscis length, and currently lowland species have longer proboscides. Proboscis length dictates the types of flowers that bumblebees can feed on and fertilise. Altered distributions of bumblebees resulting from climate change therefore also alters the type of flowers that will be fertilised by the bees along the altitudinal gradient. Climate change thereby has the potential not only to affect the bee community itself but also the plants on which it feeds [17].

This example demonstrates very clearly that the biotic interdependence of species causes cascading effects within the community as a result of range shifts, or addition and removal of species. One of the greatest current challenges in understanding the consequences of climate change, and which is a focus of Climate Change Responses, is to disentangle interactions among organisms, and those between organisms and the environment [18]. A prime example of this challenge is in understanding how changes in abiotic conditions influence trophic interactions among species. For example, different responses to long-term temperature changes altered the interactions between a fish predator and its prey in different thermal environments [19]. Herbivore abundance can also be strongly influenced by abiotic conditions, while simultaneously affecting predator dynamics. Vice versa, the presence of predators can alter herbivore behaviour and abundance. It is conceivable therefore, that changes in the abiotic environment modify the interactions between herbivores and their predators. However, in this issue of Climate Change Responses, Brodie et al. show that the presence of wolves did not alter the responses to changing snow cover in mature female and juvenile elk, both of which responded negatively to increasing snowpack regardless of the presence of predators [20]. These results emphasise that climate and weather need to be considered at the local, ecologically relevant level [7], and that the effect of changing environmental conditions can persist regardless of predator presence. To complicate matters further, the interaction between environmental drivers can change the interaction between organisms [21]. Hence, the interactions between $\mathrm{CO}_{2}$, temperature, UV-B radiation, and rainfall influence interactions between plants and herbivorous invertebrates. Most of the effects of interactions between climate drivers were multiplicative, with some antagonistic but very few synergistic effects [21].

The articles published in the first edition of Climate Change Responses reflect the nature of the challenges deriving from biological complexity that need to be addressed to predict and manage the effects of climate change on populations, communities, and ecosystems. These inaugural papers also set the tone for the journal and will, we intend, encourage participation from our colleagues to make this one of the premier journals in the field.

\section{Competing interests}

The authors declare that they have no competing interests.

\section{Authors' contributions}

Both authors contributed equally to writing this editorial. Both authors read and approved the final manuscript.

\section{Author details}

'Department of Biology, Penn State University, 208 Mueller Lab, University Park, PA 16802, USA. ${ }^{2}$ School of Biological Sciences, University of Sydney, Sydney, NSW 2006, Australia.

Received: 22 September 2014 Accepted: 24 September 2014

Published online: 22 October 2014

\section{References}

1. Urban MC, Holt RD, Gilman SE, Tewksbury J: Heating up relations between cold fish: competition modifies responses to climate change. J Anim Ecol 2011, 80:505-507. 
2. Urban MC, Tewksbury JJ, Sheldon KS: On a collision course: competition and dispersal differences create no-analogue communities and cause extinctions during climate change. Proc Roy Soc B 2012, 279:2072-2080.

3. Zarnetske PL, Skelly DK, Urban MC: Biotic multipliers of climate change. Science 2012, 336:1516-1518

4. Stocker TF, Qin D, Plattner G-K, Alexander LV, Allen SK, Bindoff NL, Bréon F-M, Church JA, Cubasch U, Emori S, Forster P, Friedlingstein P, Gillett N, Gregory JM, Hartmann DL, Jansen E, Kirtman B, Knutti R, Krishna Kumar K, Lemke P, Marotzke J, Masson-Delmotte V, Meehl GA, Mokhov II, Piao S, Ramaswamy V, Randall D, Rhein M, Rojas M, Sabine C, et al: Technical Summary. In Climate Change 2013: The Physical Science Basis Contribution of Working Group I to the Fifth Assessment Report of the Intergovernmental Panel on Climate Change. Edited by Stocker TF, Qin D, Plattner G-K, Tignor M, Allen SK, Boschung J, Nauels A, Xia Y, Bex V, Midgeley PM. Cambridge, UK: Cambridge University Press; 2014:1-84.

5. Padilla-Gamino JL, Kelly MW, Evans TG, Hofmann GE: Temperature and $\mathrm{CO} 2$ additively regulate physiology, morphology and genomic responses of larval sea urchins, Strongylocentrotus purpuratus. Proc Roy Soc B 2013, 280:20130155-20130155

6. van Uitregt VO, Wilson RS, Franklin CE: Cooler temperatures increase sensitivity to ultraviolet $B$ radiation in embryos and larvae of the frog Limnodynastes peronii. Global Change Biol 2007, 13:1114-1121.

7. Helmuth B, Russell BD, Connell SD, Dong Y, Harley CDG, Lima FP, Sara G, Williams GA, Mieszkowska N: Beyond long-term averages: making biological sense of a rapidly changing world. Climate Change Responses 2014, 1:10-20,

8. Bateson P, Barker D, Clutton-Brock T, Deb D, Dudine B, Foley RA, Gluckman P, Godfrey K, Kirkwood T, Lahr MM, McNamara J, Metcalfe NB, Monaghan P, Spencer HG, Sultan SE: Developmental plasticity and human health. Nature 2004, 430:419-421.

9. Danysh HE, Gilman RH, Wells JC, Pan W, Zaitchik B, Gonzalvez G, Alvarez M, Checkley W: EI Niño adversely affected childhood stature and lean mass in northern Peru. Climate Change Responses 2014, 1:10-20.

10. Stubbs JL, Kearney MR, Whiting SD, Mitchell NJ: Models of primary sex ratios at a major flatback turtle rookery show an anomalous masculinising trend. Climate Change Responses 2014, 1:20-30.

11. Wolkovich EM, Cook BI, Allen JM, Crimmins TM, Betancourt JL, Travers SE, Pau S, Regetz J, Davies TJ, Kraft NJB, Ault TR, Bolmgren K, Mazer SJ, McCabe GJ, McGill BJ, Parmesan C, Salamin N, Schwartz MD, Cleland EE: Warming experiments underpredict plant phenological responses to climate change. Nature 2013, 485:494-497.

12. CaraDonna PJ, ller AM, Inouye DW: Shifts in flowering phenology reshape a subalpine plant community. Proc Natl Acad Sci 2014, 111:4916-4921.

13. Diamond SE, Frame AM, Martin RA, Buckley LB: Species' traits predict phenological responses to climate change in butterflies. Ecology 2011, 92:1005-1012.

14. McMahon SM, Harrison SP, Armbruster WS, Bartlein PJ, Beale CM, Edwards ME, Kattge J, Midgley G, Morin X, Prentice IC: Improving assessment and modelling of climate change impacts on global terrestrial biodiversity. Trends Ecol Evol 2011, 26:249-259.

15. Skelly DK, Joseph LN, Possingham HP, Freidenburg LK, Farrugia TJ, Kinnison MT, Hendry AP: Evolutionary responses to climate change. Conservation Biol 2007, 21:1353-1355.

16. Hoffmann $A A$, Sgrò CM: Climate change and evolutionary adaptation. Nature 2011, 470:479-485.

17. Pradervand J-N, Pellissier L, Randin CF, Guisan A: Functional homogenization of bumblebee communities in alpine habitats. Climate Change Responses 2014, 1:10-20

18. Post E: Ecology of Climate Change. Princeton, NJ, U.S.A: Princeton University Press; 2013

19. Grigaltchik VS, Ward AJW, Seebacher F: Thermal acclimation of interactions: differential responses to temperature change alter predator-prey relationship. Proc Roy Soc B 2012, 279:4058-4064.
20. Brodie JJ, Post E, Berger J, Watson F: Trophic interactions and dynamic herbivore responses to snowpack. Climate Change Responses 2014, 1:10-20.

21. Rosenblatt AE, Schmitz OJ: Interactive effects of multiple climate change variables on trophic interactions: a meta-analysis. Climate Change Responses 2014, 1:20-30

doi:10.1186/s40665-014-0005-1

Cite this article as: Post and Seebacher: Addressing new challenges in climate change research by highlighting biological complexity. Climate Change Responses 2014 1:5.

\section{Submit your next manuscript to BioMed Central and take full advantage of:}

- Convenient online submission

- Thorough peer review

- No space constraints or color figure charges

- Immediate publication on acceptance

- Inclusion in PubMed, CAS, Scopus and Google Scholar

- Research which is freely available for redistribution

Submit your manuscript at www.biomedcentral.com/submit
( BioMed Central 